九州大学学術情報リポジトリ

Kyushu University Institutional Repository

\title{
Manufacturing Flame-Retardant Panels from Japanese Cedar by the Pressure Process Combined with Hot Pressing Techniques
}

\section{LinHan Chien}

Depatrment of Forest products Science, College of Agriculture, National Chiayi Unviersity

Ohuchi, Takeshi

Faculty of Agriculture, Kyushu University

Murase, Yasuhide

Faculty of Agriculture, Kyushu University

Shiah, Tsang-Chy i

Division of Forestry Chemistry, Taiwan Forestry Research Institute

https://doi.org/10.5109/4646

出版情報：九州大学大学院農学研究院紀要. 50 (2)，pp. 327-341，2005-10-01. Faculty of Agriculture, Kyushu University

バージョン：

権利関係： 


\title{
Manufacturing Flame-Retardant Panels from Japanese Cedar by the Pressure Process Combined with Hot Pressing Techniques
}

\author{
Han Chien LIN ${ }^{1}$, Takeshi OHUCHI' ${ }^{2}$, Yasuhide MURASE ${ }^{2}$, \\ and Tsang-Chyi SHIAH ${ }^{3, *}$
}

\author{
Laboratory of Wood Material Technology, Division of Biomaterial Science, \\ Department of Forest and Forest Products Sciences, Faculty of Agriculture, \\ Kyushu University, Fukuoka 812-8581, Japanese \\ (Received June 24, 2005 and accepted July 26, 2005)
}

\begin{abstract}
This investigation used Japanese cedar (Cryptomeria japonica D. Don.) as a material, one of the main plantations in Taiwan. After first having been through the pressure treatment process with a commercial fire retardant chemical (FR), the flame-retardant panels, for indoor use, were manufactured using the hot pressing method. The objective of this research was to increase the value-added dimension of the end product, thereby increasing the utilization of Taiwan's plantations. The hope was to enable Japanese cedar plantations in Taiwan to improve upon their economic efficiency by providing information to forestry industry workers, interior decorators, and finishing material suppliers, thereby increasing the profit indirectly for the forestry workers in charge of their own forest. The results obtained showed that the flame retardancy of the panels was substantially increased after being pressure treated with FR and then hot pressed. In addition, the physical properties improved as well. The results of the micrographic and soft X-ray analysis showed that FR occurred inside the cell cavity or lumen of the panels, and resulted in a higher surface density of the panels, reaching up to $1.80 \mathrm{~g} / \mathrm{cm}^{3}$. Based on the results of this study, hot pressing for $30 \mathrm{~min}$ with $4 \mathrm{MPa}$ at $120^{\circ} \mathrm{C}$ was able to qualify for CNS 11668, and reach the second grade of CNS 7614 as well.
\end{abstract}

\section{INTRODUCTION}

The Taiwan Forestry Bureau reported in the third survey of forest resources (1995) that forests occupied 2102400 hectares (ha), or $58.53 \%$ of the total island area (3 591 $500 \mathrm{ha}$ ) of Taiwan. Of these forests, $77.7 \%$ is natural forest, followed by $20.3 \%$ plantations and others. Hardwood forests occupies $1120400 \mathrm{ha}$, and are the major forest type on the island, followed by conifer forests at 438500 ha, then a further 391200 ha of mixed conifer and hardwood forests, and the rest consists of 152300 ha of bamboo forests. The total forest volume of the island amounts to about 358744000 cubic meters $\left(\mathrm{M}^{3}\right)$. Among these forests, Japanese cedar (Cryptomeria japonica D. Don), one of the main plantation species, occupies $39100 \mathrm{ha}$, which is about one-tenth of all plantations. The volume of Japanese cedar is about $9330000 \mathrm{M}^{3}$. Plantations need to be thinned, and this

\footnotetext{
1 Department of Forest Products Science, College of Agriculture, National Chiayi University, Chiayi, Taiwan, ROC.

2 Laboratory of Wood Material Technology, Division of Biomaterial Science, Department of Forest and Forest Products Sciences, Faculty of Agriculture, Kyushu University, Japanese.

${ }^{3}$ Division of Forestry Chemistry, Taiwan Forestry Research Institute, Taipei, Taiwan, ROC.

* Corresponding author (E-mail: ccshiah@serv.tfri.gov.tw)
} 
is normally done by mechanical means. These thinned woods are generally called "smalldiameter $\log$ (SDL)". It has long been known that there are many reasons why these SDLs must be removed, including reducing the forest fire hazard, managing the stand species and mix to a more desirable composition, providing a better wildlife habitat, protecting watersheds, and so on (Levan-Green and Livingston, 2001). However, SDLs are rarely employed because of low density, high knots, etc. The Japanese cedar especially is under-utilized in Taiwan.

Over the past decades, the utilization of SDLs has been concentrated on traditional uses, such as nonstructural lumber, pulp, chips, firewood, etc., but this is rapidly being changed over the past few years. Value-added has become the key word for SDLs, such as, paneling, biomass energy, composting, laminating, and so on. This is mainly because wood is regarded as one of the green or environmentally friendly materials as well as a renewable resource. Some researchers using SDLs as a material, applied hot pressing techniques, steam-treatments or heat-treating methods, to modify the properties of the SDL materials. The results have shown that surface hardness, modulus of rupture (MOR), modulus of elasticity (MOE), and compressive strength can be increased. In addition boards manufactured from SDLs and then treated can be given a higher surface density. In other words, they managed to obtain densification on the surface of the SDL products (Tsai et al., 1995; Chen et al., 2000; Kim H. G. and Kim K. T., 2000; Hwang, 2003).

Wood has many good properties (environmentally, aesthetically, as well as physical and mechanical properties, and can be easily processed, etc.) and is widely used in the building industry as a construction material. Furthermore, wood is a renewable raw material, and is easy to recycle or dispose off (Kuwahara, 1996). The use of wood is becoming very popular not only for family houses, but also for public places. However, the use of Japanese cedar, one of the main plantations in Taiwan, as an interior material, in paneling or as a veneer, in residential building is much less. This is because of its flammability (Okuma, 1998), in addition to the low density and higher knots. At present in many countries fire regulations are being modified to allow the use of wood or wood-based materials, such as CNS 7614, CNS 8736, etc in Taiwan. It is expected that there will be a growing demand for pressure treated flame retardant wood products.

In order to add value to SDLs and obtain a panel material with a higher fire safety rating, a commercial fire retardant chemical was employed. The hot pressing technique and the pressure treating process were combined. The goal of this present study was to manufacture a flame-retardant panel from Japanese cedar by treating it with fire retardants using the pressure process, and then applying the hot press technique. The properties of the panels: density, moisture content, hygroscopic/water absorption, contact angle, color change, surface texture, etc were examined. The flame retardant performance of the panels was measured according to CNS 11668 and CNS 7614, and the thermal behavior of the panels was investigated using thermogravimetric analysis (TGA). In order to verify the fire retardant in the panel, as well as to determine panel surface densification, micrographs and the density profile of the cross section of the panels were examined using a scanning electron microscope (SEM), and soft X-ray analysis were made. 


\section{MATERIALS AND METHODS}

\section{Specimen preparations}

In these experiments small-diameter logs (SDLs) of Japanese cedar (Cryptomeria japonica D. Don) were obtained from the Alishan 141 area of the Taiwan Bureau of Forestry. The age gradation ranged between 24 to 32 years, and the distribution of the breast height diameter (BHD) was about 20 to $30 \mathrm{~cm}$. The panel specimens were sawn using a simple sawing method, and they were air-dried for over 4 weeks. The specimens that were tested for various properties measured $300 \mathrm{~mm} \times 100 \mathrm{~mm} \times 15 \mathrm{~mm}$ thick, and for the flammability tests they measured $300 \mathrm{~mm} \times 150 \mathrm{~mm} \times 15 \mathrm{~mm}$ thick. All specimens were kept at $20^{\circ} \mathrm{C}$ with $65 \%$ relative humidity $(\mathrm{RH})$ for about four weeks. The average moisture content was $9.1 \pm 0.2 \%$ and the density at this moisture content was $0.31 \pm$ $0.04 \mathrm{~g} / \mathrm{cm}^{3}$.

\section{Fire retardant chemical}

The contents (by weight) of the commercial fire retardant chemical (FR) used in this study are as follows:
a. $9 \%$ diammonium hydrogen phosphate;
b. $6 \%$ urea;
c. $9 \%$ phosphoric acid;
d. $14 \%$ ammonium polyphosphate;
e. $62 \%$ water.

The commercial FR, one of the types of phosphonates (GP-202, Indoor type of High Efficiency Lumber Fireproof Lotion), was provided by Great \& Power Top Co. Ltd., Taiwan. The percentage of solid contents was about $25.3 \%$ after having been placed into a convection oven at $105^{\circ} \mathrm{C}$ for over $3 \mathrm{~h}$, and the range of the $\mathrm{pH}$ value was 7.0 to 7.4.

\section{Manufacture of panel specimens}

The panel specimens were processed with the FR, using a pressure process cylinder (TPC-10, Taishin Industry Co. Ltd., Taiwan) for the full-cell treatment process. The volume was kept for $30 \mathrm{~min}$ at $600 \mathrm{~mm} / \mathrm{Hg}$, and then impregnated with FR. Subsequently, the pressure was increased in the range of about 0.3 to $0.4 \mathrm{MPa}$, and was maintained in this condition for 3 different periods, $30,60,120 \mathrm{~min}$, respectively. The abbreviation of the specimen codes was P30HP, P60HP, and P120HP respectively. These specimens were removed to a drainage pad, and tipped on end to allow for drainage. The specimens were then briefly wiped with paper towels to remove surface FR, and then measured to determine the impregnation. The specimens were air-dried for $24 \mathrm{~h}$, and then placed into a convection oven at $30^{\circ} \mathrm{C}$ for over $30 \mathrm{~min}$ after which they were cooled and stored in plastic bags for at least 3 days to allow the FR fixation reaction to proceed. Afterwards, panels were individually manufactured by hot pressing at $4 \mathrm{MPa}$, at $120^{\circ} \mathrm{C}$, for $30 \mathrm{~min}$, with the distance bars at $12 \mathrm{~mm}$ (panel thickness), and reconditioned at $20^{\circ} \mathrm{C}$ with $65 \%$ RH for about 3 weeks. Thirty six panel specimens were prepared.

\section{Calculation of retention}

The impregnation was calculated using the following equation: 
Impregnation $\left(\mathrm{kg} / \mathrm{m}^{3}\right)=(\mathrm{W} a-\mathrm{W} b) \mathrm{C} / \mathrm{V}$

Where $\mathrm{W} a$ is the weight of the specimen after the pressure process treatment, depending upon the time periods; $\mathrm{Wb}$ is the specimens weight prior to any process; $\mathrm{C}$ (\%, $\mathrm{w} / \mathrm{w})$ is the concentration of the $\mathrm{FR} ; \mathrm{V}$ is the dimension of the specimen $\left(\mathrm{L}^{*} \mathrm{~W}^{*} \mathrm{~T}\right)$.

\section{Tests of surface texture}

Using a surface texture-measuring instrument (Semitsu, Tokyo), the surface texture of the specimens were measured for each type of panel, after each pressure process with the hot pressing. This measurement involved the texture degree of both the vertical and horizontal fiber directions at the surface of the specimen. The average degree of the surface texture on the centerline of the specimen $(\mathrm{Ra})$, the degree of the texture at the maximum high point on the surface of the specimen (Rmax), and the average degree of the texture for ten points on the surface of the specimen $(\mathrm{Rz})$ were examined.

\section{Analysis of color change}

The control specimens (untreated panel specimens, $12 \mathrm{~mm}$ thick), HP (the panel was treated with the hot pressing only), P30HP, P60HP, and P120HP were measured using a Colorimeter (Nippon Denshoku NR-3000) at 6 randomly selected spots. In the CIE 1976 $\mathrm{L}^{*} \mathrm{a}^{*} \mathrm{~b}^{*}$ color system employed in this study, color is considered to consist of three major dimensions: hue, chroma, and lightness. $L^{*}$ is the lightness or brightness variable and is generally the most important aspect of wood color changes to a viewer's eye. $a^{*}$ and $b^{*}$ represent the chromaticity (hue and chroma) coordinates.

\section{Measurement of contact angle}

The $50 \mathrm{~mm}$ square specimens were cut and then prepared to evaluate the contact angle. The contact angle with six replicates on each panel surfaces was measured using a contact angle meter (Face contact angle meter CA-D, Kyowa meter FACE science Co. Ltd.).

\section{Tests of hygroscopic/water absorption}

The hygroscopic/water absorption and thickness swelling were measured, and then calculated, respectively, using the following equations:

Hygroscopic percent $(h, \%)=\left(h_{b}-h_{a}\right) / h_{a} \times 100$

Where $h_{\iota}$ is the specimen weight after it is placed into a humidified cabinet (LH-112, Tabai Espec Corp.), setting the conditions at $40 \pm 1{ }^{\circ} \mathrm{C}$ and $75 \pm 2 \% \mathrm{RH}$, for 6,24 or $72 \mathrm{~h}$; $\mathrm{h}_{a}$ is the weight of the specimen before it is placed into the cabinet:

Water absorption $(u, \%)=(\mathrm{W} u-\mathrm{Wo}) / \mathrm{Wo} \times 100$

Where $\mathrm{W} u$ is the specimen weight after having been placed in water for 2 or $24 \mathrm{~h}$; Wo is the weight of the specimen after it has been placed into an oven at $105 \pm 2{ }^{\circ} \mathrm{C}$ for over $24 \mathrm{~h}$.

Thickness swelling $(t, \%)=(t u-t a) / t a \times 100$

Where $t u$ is the specimen thickness after having been placed in water for 2 or $24 \mathrm{~h} ; t a$ is the specimen thickness before it is placed in the water. 


\section{Microscopic observation}

Samples, with a cross section of $0.5 \mathrm{~cm} \times 0.5 \mathrm{~cm}$, were made of the panel specimens as they were subjected to the various manufacturing conditions of this study. The samples for microscopic observation were oven-dried. An area of each sample was sputter coated with gold-palladium, and then observed using a Scanning Electron Microscope (SEM, HITACH S-2400 types).

\section{Soft X-ray analysis}

Using the soft X-ray equipment (SOFTEX Type CMBW, Softex Co. Ltd.) in Kyushu University, Fukuoka, Japan, the distribution of the density profile for various panel specimens was investigated after the panels were cut to a size of $5 \mathrm{~mm} \times 100 \mathrm{~mm}(\mathrm{~L} \times \mathrm{W})$ $\times$ panel thickness. The experimental conditions were set at $30 \mathrm{kVp}$ of diode transistor logic (DTL) Volt, and $10 \mathrm{~mA}$ of DTL ampere with a distance of $120 \mathrm{~mm}$ between specimens and film, with the irradiation time set at $90 \mathrm{sec}$. The images were digitally recorded and stored on a personal computer. The image area and the concentration of each contrast sample were analyzed using Win Roof software (Mitani Corporation, Version 3.03). The density profile for each processed panel was obtained after the concentration of each control specimen on the film was first calibrated.

\section{Thermogravimetric analysis (TGA)}

Thermogravimetric analysis (TGA) is a common technique for measuring the weight change of a material as a function of temperature. Throughout this research project, TGA was carried out using a Perkin-Elmer TGA 1, USA, fully supported by computer-controlled software options, from Perkin-Elmer Thermal Analysis Systems, for control and data handling. The samples, approximately $5.0-10.0 \mathrm{mg}$ in weight, were placed into an open experimental sample pan, and suspended from a sensitive microbalance. A furnace surrounded the sample to provide accurate heating from 50 to $800^{\circ} \mathrm{C}$, while the measurement was taking place. In order to isolate the pyrolysis step, considered the most important step in the burning process for materials, a nitrogen atmosphere was selected for the TGA analysis (Hsu et al., 2000). All runs were purged in nitrogen atmosphere, at a flow rate of $50 \mathrm{ml} / \mathrm{min}$, and a heating rate of $20^{\circ} \mathrm{C} / \mathrm{min}$. The thermal behavior for the different types of panels, Japanese cedar (the control specimen), and FR was then analyzed.

\section{Tests of flammability performance}

The specimens for various panels measured $300 \mathrm{~mm} \times 150 \mathrm{~mm} \times 12 \mathrm{~mm}$. The flammability performance was investigated using a flammability test cabinet which was custom-made in accordance with CNS 7614 and CNS 8736. The fuel used was liquid propane. The specimen was burned with a Bunsen burner after it was adjusted to pale blue flame of about $6 \mathrm{~cm}$ in height. The flame temperature, about $620^{\circ} \mathrm{C}$, was verified using a temperature-element apparatus. (SUNTEX, ST-54). The heating time was set for $2 \mathrm{~min}$. The items tested for flammability performance included afterflame, afterglow, length of char, and area of char. The area of char was measured with an auxiliary sheet, DT-42. According to CNS 11668 and CNS 7614, the obtained value was qualified and then the grade of flame retardancy was determined. 


\section{Statistics analysis}

Results of surface texture, color change, contact angle, hygroscopic/water absorption, thickness swelling, and flammability performance were statistically analyzed based on Duncan's multiple range tests at 5\% significant level analysis, using the Statistical Package for Social Science (SPSS) software.

\section{RESULTS AND DISCUSSION}

To examine the flame-retardant panels (HP, P30HP, P60HP, and P120HP) using a hot pressing of $4 \mathrm{MPa}$, at $120^{\circ} \mathrm{C}$, for $30 \mathrm{~min}$ after first having been treated for different periods at $30,60,120 \mathrm{~min}$ with the full-cell process, several properties were carried out and compared to the control panel (12 $\mathrm{mm}$ in thickness). The average compression ratio for the panels after the hot pressing was about $17.22 \pm 2.58 \%$, indicating that the thickness of the panel specimens was about 12.03 to $12.80 \mathrm{~mm}$. After reconditioning, the range of moisture content for the flame-retardant panels was $7.7 \pm 0.4$ to $8.9 \pm 0.4 \%$. The density at this moisture content was about $0.42 \pm 0.02 \mathrm{~g} / \mathrm{cm}^{3}$ for HP, but it reached about $0.46 \pm 0.02 \mathrm{~g} / \mathrm{cm}^{3}$ for the others with FR. For the amount of impregnation, the results obtained that P120HP was $25.00 \pm 3.49 \mathrm{~kg} / \mathrm{m}^{3}$, followed by $22.50 \pm 3.17 \mathrm{~kg} / \mathrm{m}^{3}$ for P $60 \mathrm{HP}$, and $16.66 \pm 2.64 \mathrm{~kg} / \mathrm{m}^{3}$ for P30HP. Based on the change period, the difference in impregnation was significant (5\%) by Duncan's multiple range tests, expressed by different alphabets. It is suggested that the impregnation of the panels increased with the increase in time period with pressure process at 0.3 to $0.4 \mathrm{MPa}$.

\section{Properties of flame-retardant panels}

The influences of the surface texture of various panels on the degree of texture of the horizontal and vertical fiber directions were investigated. The results are shown in Table 1. Compared to the control specimens, the surface texture, expressed Ra, Rmax, and Rz, of either type of specimen on either the horizontal or the vertical fiber direction was significant by Duncan's multiple range tests, expressed by different alphabet, even for the specimens with different time period. In addition to $\mathrm{Ra}$ and $\mathrm{Rmax}$ the vertical fiber direction for P60HP was unchanged after Duncan's statistics analysis, expressed by the same alphabet. The above results suggest that in order to obtain a better surface on the final product, the panels need to have their surface refinished after they have been subjected to some kind of water solution.

Generally speaking, color changes are the most important aspect of wood or/and wood-based materials to the industrial viewer's eyes, and $\mathrm{L}^{*} \mathrm{a}^{*} \mathrm{~b}^{*}$ are the most frequently measured parameters (Okano et al., 1995). Results of colorimetric measurements of the panel specimens, before and after processing for various time periods at 0.3 to $0.4 \mathrm{MPa}$ of the pressure process with the hot pressing, based on the CIE $L^{*} a^{*} b^{*}$ system are presented in Table 2. It obtained that $\mathrm{L}^{*} \mathrm{a}^{*} \mathrm{~b}^{*}$ for the panel specimens were insignificantly changed. This is because of the type of experimental material used; Japanese cedar has a deeply colored heartwood. The results also showed that the difference in degree of chroma for red $\left(\Delta \mathrm{a}^{*}\right)$ changed to a minus direction and the yellow $\left(\Delta \mathrm{b}^{*}\right)$ decreased. According to the different time periods, the color difference $(\Delta E)$ was 
Table 1. Surface texture of various panel specimens.

Unit: $\mu \mathrm{m}$

\begin{tabular}{|c|c|c|c|c|c|c|}
\hline \multirow{2}{*}{ Panel code } & \multicolumn{3}{|c|}{ Texture degree to horizontal fiber direction } & \multicolumn{3}{|c|}{ Texture degree to horizontal fiber direction } \\
\hline & $\mathrm{Ra}^{1)}$ & $\operatorname{Rmax}^{1)}$ & $\mathrm{Rz}^{1)}$ & $\mathrm{Ra}^{1)}$ & $\mathrm{Rmax}^{1)}$ & $\mathrm{Rz}^{1)}$ \\
\hline & 2.87( & .71 & 15.92( & & 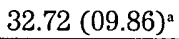 & \\
\hline $\mathrm{HP}$ & 1.33( & 10.48 & 7 & & 13. & $.80)^{4}$ \\
\hline $\mathrm{P} 30 \mathrm{H}$ & 4.50( & 14.76 & $9.37(2$. & (2. & $26.57(10.82)^{c}$ & $17.99(7.19)$ \\
\hline & 0.04 & 14. & 9.99 & ac & $30.31(12.12)^{a}$ & $19.30(7.86)$ \\
\hline & $4.09(1.05)^{\mathrm{c}}$ & $15.83(4.90)^{\mathrm{c}}$ & $10.21(3.71)^{\mathrm{c}}$ & $7.96(4.63)^{\mathrm{c}}$ & $26.66(14.45)^{c}$ & $17.67(8.60)$ \\
\hline
\end{tabular}

1) $\mathrm{Ra}$ : The average degree of the surface texture on the centerline of the specimen; Rmax: the degree of the texture at the maximum high point on the surface of the specimen; Rz: the average degree of the texture for ten points on the surface of the specimen.

2) Mean (standard error) separation within columns by Duncan's multiple range tests at 5\% significant level. Same alphabet is defined as insignificant difference between two variable factors. On the contrary, significant difference is expressed by different alphabet.

3) Control: control specimen (Japanese cedar), HP: Hot pressing; P30HP: Hot pressing after pressure process of $30 \mathrm{~min}$; P60HP: Hot pressing after pressure process of $60 \mathrm{~min}$; P120HP: Hot pressing after pressure process of $120 \mathrm{~min}$.

Table 2. Color differences of various panel specimens.

\begin{tabular}{|c|c|c|c|c|c|c|c|}
\hline Pane & $\mathrm{L}^{* 1)}$ & $a^{* 1)}$ & $\mathrm{b}^{* 1)}$ & $\Delta \mathrm{L}^{* 2)}$ & $\Delta a^{* 2)}$ & $\Delta \mathrm{b}^{* 22}$ & $\Delta \mathrm{E}^{2)}$ \\
\hline Cont & $7.35(1.87)^{4)}$ & $9.45(1.01)$ & $8.47(0.90)$ & - & - & - & - \\
\hline $\mathrm{HP}^{3)}$ & $5.19(2.12)$ & 10.64( & $20.25(1.01)$ & $-2.18(0.09)$ & $1.19(0.17)$ & $1.78(0.70)$ & $3.06(0.90)^{\text {adf }}$ \\
\hline 305 & 56690 & 8.220 & 19.27 & $-0.68(0.59)$ & $-1.23(0.65)$ & 2) & $(0.27)^{b}$ \\
\hline P60HP ${ }^{3)}$ & $54.77(1.98)$ & $8.84(1.13)$ & $18.84(1.45)$ & $-2.60(0.78)$ & $-0.61(0.27)$ & $0.37(0.26)$ & $2.69(0.38)^{\mathrm{ab}}$ \\
\hline P120HP3) & $57.02(1.91)$ & $7.64(0.64)$ & $18.70(0.80)$ & $-0.35(0.23)$ & $-1.81(0.42)$ & $0.23(0.18)$ & $1.85(0.18)^{\mathrm{b}}$ \\
\hline
\end{tabular}

1) Color values: $\mathrm{a}^{*}: 0$ to +60 Red direction, 0 to -60 Green direction; $\mathrm{b}^{*}$ : 0 to +60 Yellow direction, 0 to -60 Blue direction. $\mathrm{L}^{*}: 0$ to 50 Dark direction, 51 to 100 Light direction.

2) $\Delta \mathrm{L}^{*}=\mathrm{L}_{\text {control }} *-\mathrm{L} i ; \Delta \mathrm{a}^{*}=\mathrm{a}_{\text {control }}{ }^{*}-\mathrm{a} i ; \Delta \mathrm{b}^{*}=\mathrm{b}_{\text {control }}{ }^{*}-\mathrm{b} i$, where $i=\mathrm{HP}$ or P30HP or P60HP or P120HP; $\Delta \mathrm{E}=$ $\left(\Delta \mathrm{L}^{* 2}+\Delta \mathrm{a}^{* 2}+\Delta \mathrm{b}^{* 2}\right)^{1 / 2}$ : Color difference.

3) and 4) The notes are the same as Table $1^{2 \text { ) and } 3 \text { ). }}$

significant (5\%) by Duncan's multiple range tests. The panel specimens, after first having been through the pressure process with a commercial FR and then having been hot pressed, substantially changed in surface color.

The contact angle is regarded as an important parameter in interface science; it is a common measure of wettability (hydrophobic/hydrophilic property) of a solid surface. This is because the contact angle measurements can be used in the evaluation of wettability and adhesion (Lam, 2002). The results of the contact angle of various panel specimens are shown in Table 3. As expected, the contact angle changed for each type of specimen. The contact angle of $69.0^{\circ}$ for the control specimen was smaller than that of the other panels, followed $78.5^{\circ}$ for HP and P30HP, $77.5^{\circ}$ for P60HP and $75.5^{\circ}$ for P120HP. According to the panels with or without FR in the pressure process, the difference of contact angle was significant (5\%) by Duncan's multiple range tests, expressed by different alphabets between the control sample and the test panels. In general, a porous material contributes to the swelling/absorption of the constituents and changes the 
direction of the micro-fibers after processing with a water type of solution (Takeuchi, 2000). This data suggests that the panels, after being manufactured with the hot pressing techniques, and using FR as in this study, will require having their surface reworked after processing.

Table 3. Contact angle of various panel specimens.

\begin{tabular}{|c|c|}
\hline Panel code & Contact angle $\left(^{\circ}\right)$ \\
\hline Control'y $^{2 y}$ & $69.0(5.8)^{\mathrm{a} 1)}$ \\
\hline $\mathrm{HP}^{2)}$ & $78.5(3.2)^{\mathrm{b}}$ \\
\hline P30HP') & $78.5(6.8)^{\mathrm{b}}$ \\
\hline P60HP') & $77.5(5.9)^{\mathrm{b}}$ \\
\hline $\mathrm{P}^{2} 20 \mathrm{HP}^{2)}$ & $75.5(4.6)^{\mathrm{b}}$ \\
\hline
\end{tabular}

To reveal the influence of FR addition to the wood subjected to hot pressing on hygroscopic/water absorption and thickness swelling of the flame-retardant panels, FR impregnated and non-impregnated panels (control specimen and HP), were subjected to relevant tests. The results are shown in Tables 4 and 5. Compared to the control specimen, the hygroscopic property, with the specimens under the conditions of $40 \pm 1^{\circ} \mathrm{C}$ and $75 \pm 2 \% \mathrm{RH}$ for 6 and $24 \mathrm{~h}$, for the panels with $\mathrm{FR}$ was significant by Duncan's multiple range tests, but not for HP. The hygroscopicity of various panels however was 2 times that of the control panel, expressed by different alphabet, for the panels in this condition for $72 \mathrm{~h}$. The results of water absorption/thickness swelling (Table 5), shows that the panels with FR after having been placed in water for $2 \mathrm{~h}$ had about one-fourth of the water absorption, and one-third of the thickness swelling compared to the control specimen and HP, as well as expressing by different alphabets in accordance with the Duncan's multiple range tests. After $24 \mathrm{~h}$ of water soaking, the water absorption was about one-second of control specimen or HP, but about the same as the thickness swelling of the control one. The above results indicate that after the pressure treatment combined with the hot pressing, the panels with FR, the types of phosphonates, yielded lower water absorption and thickness swelling than HP or the control panel. It is inferred that the densification formed on the surface of the panel, and FR filling the cell cavity or lumen of the panel, can influence the hygroscopic/water absorption and thickness swelling of the panels.

Table 4. Hygroscopicity of various panel specimens.

Unit: \%

\begin{tabular}{lccc}
\hline Panel Code & $6 \mathrm{~h}$ & $24 \mathrm{~h}$ & $72 \mathrm{~h}$ \\
\hline Control $^{2)}$ & $1.54(0.12)^{\mathrm{al}) .}$ & $1.89(0.04)^{\mathrm{a}}$ & $4.44(0.18)^{\mathrm{a}}$ \\
\hline $\mathrm{HP}^{2)}$ & $1.12(0.10)^{\mathrm{a}}$ & $1.65(0.31)^{\mathrm{a}}$ & $3.56(0.29)^{\mathrm{b}}$ \\
\hline $\mathrm{P}^{\mathrm{a}} \mathrm{HP}^{2)}$ & $2.40(0.25)^{\mathrm{b}}$ & $2.62(0.49)^{\mathrm{b}}$ & $10.14(1.29)^{\mathrm{c}}$ \\
$\mathrm{P}^{\mathrm{b}} \mathrm{HP}^{2)}$ & $1.98(0.18)^{\mathrm{b}}$ & $2.64(0.87)^{\mathrm{b}}$ & $11.99(1.36)^{\mathrm{c}}$ \\
P120HP $^{2)}$ & $1.94(0.13)^{\mathrm{b}}$ & $2.86(0.11)^{\mathrm{b}}$ & $9.01(0.14)^{\mathrm{c}}$ \\
\hline
\end{tabular}

1) aur 2) The notes are the same as Table $1^{\text {2) and 3). }}$ 
Table 5. Water absorption/thickness expansion of various panel specimens.

\begin{tabular}{|c|c|c|c|c|}
\hline \multirow{2}{*}{ Panel code } & \multicolumn{2}{|c|}{ Water absorption (\%) } & \multicolumn{2}{|c|}{ Thickness expansion (\%) } \\
\hline & $2 \mathrm{~h}$ & $24 \mathrm{~h}$ & $2 \mathrm{~h}$ & $24 \mathrm{~h}$ \\
\hline Control $^{2)}$ & $40.25(0.86)^{\mathrm{al})}$ & $67.07(2.49)^{\mathrm{a}}$ & $1.44(0.48)^{\mathrm{a}}$ & $1.84(0.22)^{\mathrm{a}}$ \\
\hline $\mathrm{HP}^{2)}$ & $41.59(3.12)^{\mathrm{a}}$ & $86.50(1.32)^{b}$ & $15.04(2.15)^{\mathrm{b}}$ & $18.45(0.89)^{\mathrm{b}}$ \\
\hline P30HP ${ }^{2)}$ & $12.11(0.88)^{b}$ & $36.63(1.56)^{c}$ & $0.57(0.52)^{\mathrm{a}}$ & $1.87(0.45)^{\mathrm{a}}$ \\
\hline $\mathrm{P} 60 \mathrm{HP}^{2)}$ & $12.92(0.98)^{\mathrm{b}}$ & $42.61(2.31)^{\mathrm{e}}$ & $0.54(0.45)^{\mathrm{a}}$ & $1.32(1.04)^{\mathrm{a}}$ \\
\hline $\mathrm{P} 120 \mathrm{HP}^{2)}$ & $10.89(0.24)^{\mathrm{b}}$ & $33.33(3.76)^{\mathrm{d}}$ & $0.43(0.50)^{\mathrm{a}}$ & $0.66(0.31)^{\mathrm{a}}$ \\
\hline
\end{tabular}

1) and 2) The notes are the same as Table $1^{2)}$ and 3 .

\section{Density profile of flame-retardant panels and SEM observations}

To improve the quality (properties), add value to SDLs, and obtain a panel material with a good fire safety rating, specimens of Japanese cedar after plain sawing were processed with FR using a combination of both the hot pressing technique and the pressure treating process. The density of the surface layer was higher than that of the

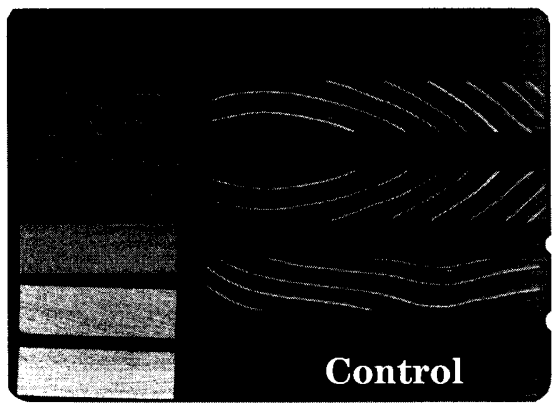

Panel specimens without hot pressing and pressure process (Untreated)

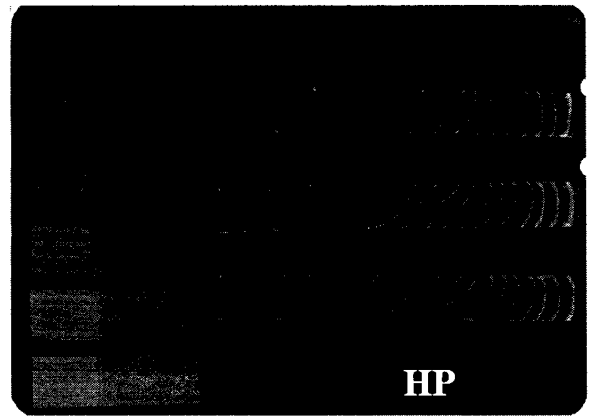

Panel specimens with hot pressing only

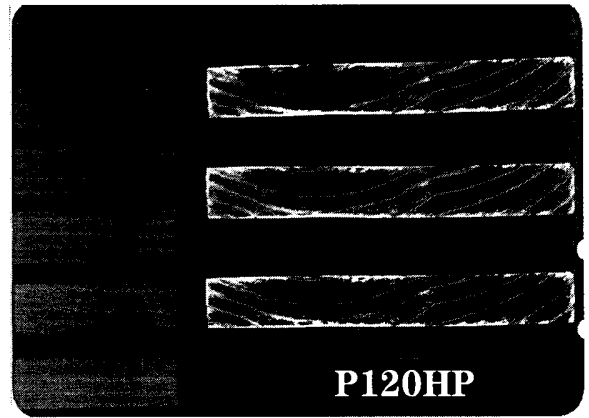

Panel specimens with hot pressing after pressure process of $120 \mathrm{~min}$.

Fig. 1. Soft X-ray film on cross sections of various panel specimens.

Note: Abbreviations of Control, HP and P120HP are the same as Table 1. 


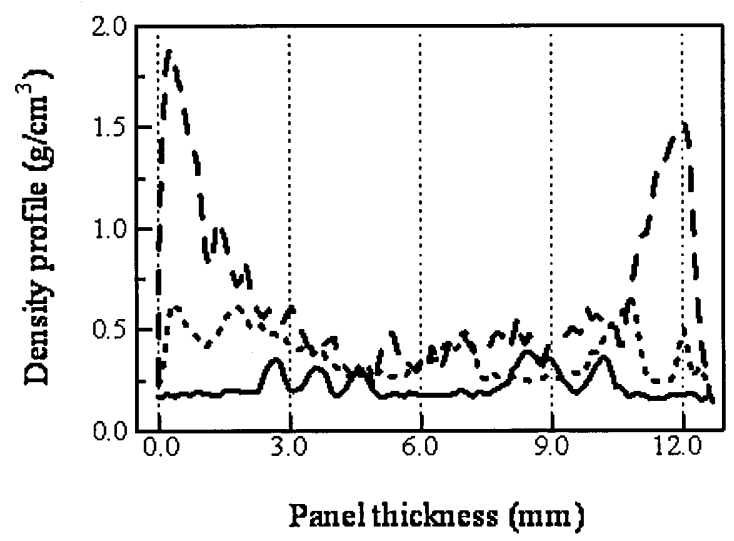

Fig. 2. Density profile of various panel specimens.

Symbols:- : Control, - - - : HP, - - - : P120HP.

Note: Abbreviations of Control, HP and P120HP are the same as Table 1.

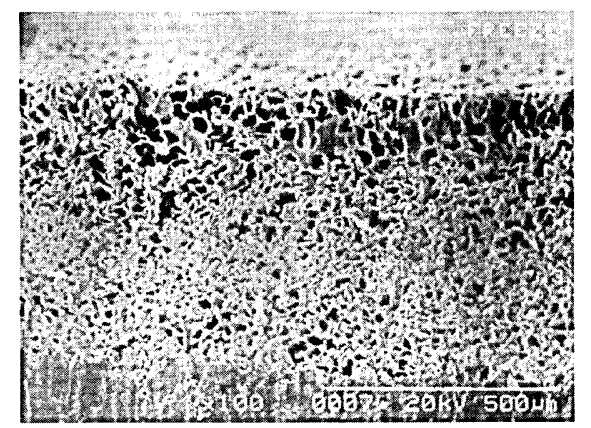

$\times 100$

Surface of panel with hot pressing (HP)

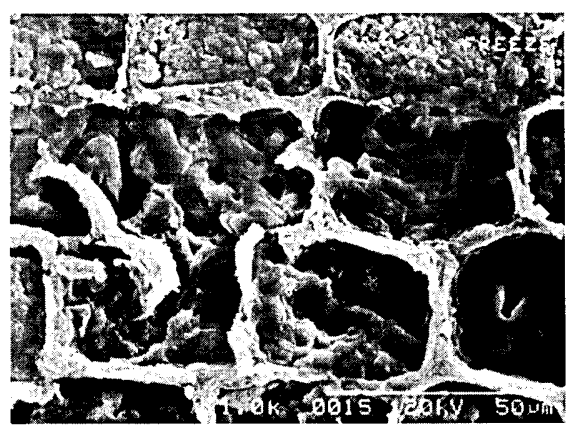

$\times 1000$, Surface of panel with hot pressing after pressure process of $120 \mathrm{~min}(\mathrm{P} 120 \mathrm{HP})$

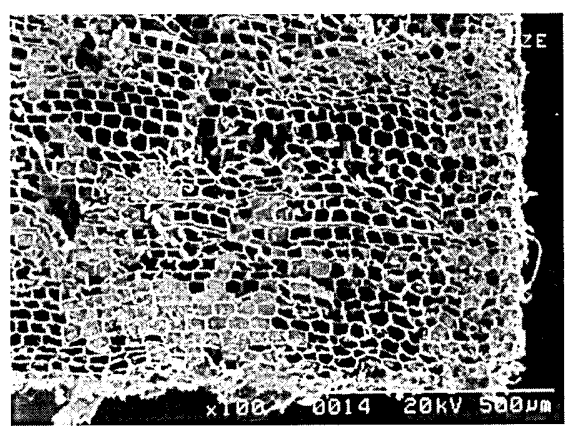

$\times 100$, Surface of panel with hot pressing after pressure process of $120 \mathrm{~min}(\mathrm{P} 120 \mathrm{HP})$

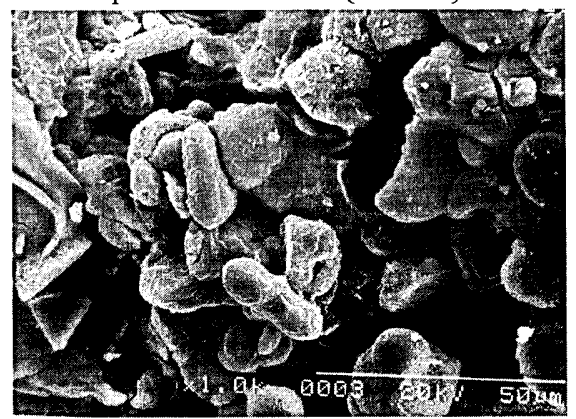

$\times 1000$, Fire retardants (FR) only

Fig. 3. Scanning electron microscope (SEM) micrographs on cross sections of various panel specimens. Note: Abbreviations of HP, P120HP and FR are the same as Table 1. 
middle layers after the combined process. The density profile of the panels and the microscopic observation of the cross section were investigated using Soft X-ray and SEM.

One example of the soft-X ray films for the control specimen, HP, and P120HP is shown in Fig. 1. The films exhibit different color densities (between gray and black color), after they were contrasted. It is shown in the growth ring in the cross section of the control panel, including in the spring (black area)/summer (gray area) wood, in the top of Fig. 1. The surface layer of HP presented a little gray color, as shown in the left bottom of Fig. 1. The film for the panels with the combination of FR processing for $120 \mathrm{~min}$ and hot pressing is shown in the right bottom of Fig. 1. The surface layer of the P120HP panel, as indicated by the gray portions, has a greater gray area than that of the control panel and HP, in addition to the gray area for the summer wood. It is evident that the surface layer was filled with FR, as well as had a higher surface density.

The density profile of the panels was obtained using the Win Roof software, as shown on Fig. 2. The surface density of the P120HP panels reached $1.80 \mathrm{~g} / \mathrm{cm}^{3}$, and $0.60 \mathrm{~g} / \mathrm{cm}^{3}$ for HP. After calculation, the average panel's density for P120HP was $0.46 \pm 0.02 \mathrm{~g} / \mathrm{cm}^{3}$, followed by $0.42 \pm 0.02 \mathrm{~g} / \mathrm{cm}^{3}$ for $\mathrm{HP}$, and $0.31 \pm 0.04 \mathrm{~g} / \mathrm{cm}^{3}$ for the control panel. The above results for the density change can be attributed to the densification on the surface of the panels due to the influence of FR and hot pressing. As expected, the micrographs of the SEM observation, shown in Fig. 3, indicate the relationships between HP and P120HP. As showing the left top of Fig 3, the wood cell form of HP on the surface is squashed due to the hot pressing (Nakamura and MItta, 1998; Chen et al., 2000). In the right top of Fig. 3, the micrograph shows that the cell wall of P120HP was also squashed and was filled with FR. This is obviously clarified in the SEM photographs with 1000 times magnification, showing that FR was inside the cell cavity or lumen of the panels on both the bottom of Fig. 3 .

\section{Thermal decomposition and flammability performance of flame-retardant panels}

TGA is an established technique, and is used in the quantification of weight changes within a material, as a function of temperature or time. To comprehend the thermal behavior (pyrolysis, thermal decomposition) of the control panel, FR, and the panel specimens were measured by TGA, after being air-dried at ambient temperatures. Decomposition profiles were obtained while being heated at a rate of $20^{\circ} \mathrm{C} / \mathrm{min}$ in nitrogen, between $50^{\circ} \mathrm{C}$ (initial temperature) and $800^{\circ} \mathrm{C}$ (end temperature). The relationships of TGA and DTG curves between temperature and weight loss, and the derivative weight for each specimen, are shown in Fig. 4.

As expected, the specimens typically show a gradual weight loss. The thermogram, resulting from the analysis of the control panel (solid line) and HP (dotted line), shows that there were two subtle changes (shoulders) at temperatures between 50 to $390^{\circ} \mathrm{C}$. It indicates that both had almost identical initial (the first sharp step) and secondary decomposition temperatures. This is supported by the derivative (DTG) curve, which shows two peaks at temperatures of 92 and $368^{\circ} \mathrm{C}$ for the control panel, and at temperatures of 82 and $362^{\circ} \mathrm{C}$ for HP (the bottom of Fig. 4). Considering the amount of char for both specimens, at a temperature of $800^{\circ} \mathrm{C}$, HP was $24.75 \mathrm{wt} \%$, but the control panel was almost zero when the temperature reached $572^{\circ} \mathrm{C}$. It is well known that the 

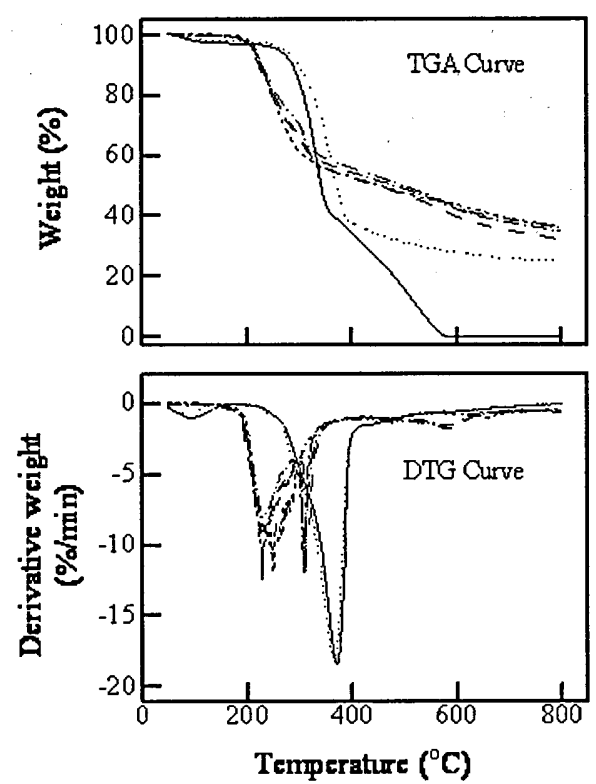

Fig. 4. TGA and DTG curves for various panel specimens and fire retardants in nitrogen at $20 \mathrm{oC} / \mathrm{min}$.

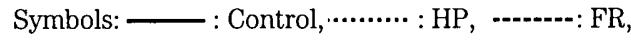
..-.-. : P30HP, -...-.-. : P60HP, - - - : P120HP.

surface layer of a panel after having been treated with hot pressing forms a densification layer (Schaffer, 1977; Yawa et al., 1997; Nakamura and MItta, 1998; Chen et al., 2000; Kim H. G. and Kim K. T., 2000), even though both of them were lower than the others (P30HP, P60HP, and P120HP). The thermal behavior of HP was therefore better than that of the control panel.

The panel specimen weights for FR (dash line), P30HP (dash dot dash line), P60HP (dash double dot line), and P120HP (long dash line) were extremely similar, showing that a same tendency was lost at temperatures from $200^{\circ} \mathrm{C}$ to about $390^{\circ} \mathrm{C}$ in the TGA tests. The DTG curve was specified in three peaks at temperatures of 224,248 and $308^{\circ} \mathrm{C}$ for all specimens (the bottom of Fig. 4). These results showed that the initial decomposition temperature $\left(224^{\circ} \mathrm{C}\right)$ of various panels was lower (quicker) than that of the control or HP. This indicated the different influence was the FR in the panels. Loidkis et al. (2003) using both $20 \%(\mathrm{w} / \mathrm{w})\left(\mathrm{NH}_{4}\right)_{2} \mathrm{HPO}_{4}$ and $\left(\mathrm{NH}_{4}\right)_{2} \mathrm{SO}_{4}$, two kinds of phosphonates, as the $\mathrm{FR}$, reported that dehydration and evolution of organic volatiles took place, followed by pyrolysis of the main constituents of cellulose, hemicellulose, lignin, etc, as well as the retardant additives shifting the primer weight loss peak, referred to as cellulose decomposition, to lower temperatures. It is suggested that the presence of FR prolonged the ignition delay time, and that this influence was more pronounced at a low temper- 
ature. The combustible volatiles are probably liberated or/and dissipated earlier, before their ignition temperature is reached. Finally, the amount of char for them left about $31.90 \mathrm{wt} \%$ to $35.72 \mathrm{wt} \%$, at a temperature of $800^{\circ} \mathrm{C}$. Because of the solid pyrolysis residue, which is directly related to the flammability properties (Loidkis et al., 2003), when comparing the char of the specimens (control and HP), the panels with FR or only FR provided a better yield of char at $800^{\circ} \mathrm{C}$.

From the results of the TGA tests, it is suggested that the thermal behavior of P30HP, $\mathrm{P} 60 \mathrm{HP}$, and P120HP is better than that of the control panel and HP, as the proposed action mechanism is based on the charred layer acting as a physical barrier, which slows down heat, and results in mass transfers between the gas and condensation phases (Camino, 1993; Hornsby, 1996; Zhu, 2001). Moreover, the fire retardants shift the DTG curve major weight loss peaks of the wood (Japanese cedar) to a lower temperature and increase the pyrolysis mass residues.

Table 6 provides an effect of flammability properties for the panel specimens with or without FR in combination with the hot pressing. Regarding the results of the afterflame, it was shown that HP, P30HP, P60HP, and P120HP were $0.0 \mathrm{sec}$, in addition to $1.0 \mathrm{sec}$ for the control panel. The difference of the afterflame was insignificant (5\%) by Duncan's multiple range tests. The afterflame of all panels was passed through CNS $11668<<10$ sec), and the second grade of CNS $7614(<5 \mathrm{sec})$. The results of the afterglow indicated that the control panel and HP could not reach out the second grade of CNS $7614(<60$ $\mathrm{sec}$ ), but not for CNS $11668(<30 \mathrm{sec})$. For three types of the panels, it was shown that the afterglow was $0 \mathrm{sec}$, indicating they were passed through both CNS. Slifka (1997) reported that the board with some hollow space (a lower density) might provide sufficient air for internal combustion, even though air is known to be a good insulator against heat transfer in large-scale structure boards. It is indicated that the cell cavity or lumen of the panels can provide the air, but these areas formed a smaller space due to the hot pressing, and were in addition filled with FR (Fig. 3) in the surface layer. The afterflame and the

Table 6. Flammability performance of various panel specimens.

\begin{tabular}{lllcc}
\hline Panel code & $\begin{array}{l}\text { Afterflam } \\
(<10 \mathrm{sec})^{\mathrm{b}} \\
(<5 \mathrm{sec})^{2)}\end{array}$ & $\begin{array}{l}\text { Afterglow } \\
(<30 \mathrm{sec})^{1)} \\
(<60 \mathrm{sec})^{2)}\end{array}$ & $\begin{array}{c}\text { Length of char } \\
-\end{array}$ & $\begin{array}{c}\text { Area of char } \\
\left(<50 \mathrm{~cm}^{2}\right)^{1)} \\
-\end{array}$ \\
\hline Control $^{4)}$ & $1.0(0.9)^{\mathrm{a} 3)}$ & $52.0(14.6)^{\mathrm{a}}$ & $14.0(1.7)^{\mathrm{a}}$ & $95.5(21.6)^{\mathrm{a}}$ \\
\hline $\left.\mathrm{HP}^{\mathrm{a}}\right)$ & $0.0(0.0)^{\mathrm{a}}$ & $50.0(25.7)^{\mathrm{b}}$ & $15.3(1.7)^{\mathrm{a}}$ & $134.5(27.1)^{\mathrm{b}}$ \\
\hline P30HP $^{4}$ & $0.0(0.0)^{\mathrm{a}}$ & $0.0(00.0)^{\mathrm{c}}$ & $8.7(0.8)^{\mathrm{b}}$ & $39.3(3.2)^{\mathrm{c}}$ \\
P60HP $^{4}$ & $0.0(0.0)^{\mathrm{a}}$ & $0.0(00.0)^{\mathrm{c}}$ & $8.7(1.2)^{\mathrm{b}}$ & $38.3(11.3)^{\mathrm{c}}$ \\
P120HP $^{4}$ & $0.0(0.0)^{\mathrm{a}}$ & $0.0(00.0)^{\mathrm{c}}$ & $8.6(1.6)^{\mathrm{b}}$ & $34.3(8.3)^{\mathrm{c}}$ \\
\hline
\end{tabular}

1) The values have to qualify under China National Standard CNS 11668 (1997) Flam-retardant plywood.

2) The values have to qualify under the second grade of China National Standard CNS 7614 (1994) Method of Test for Flammability of Thin Materials. 3) and 4) The notes are the same as Table $1^{2)}$ and 3).

afterglow were therefore extremely low, as expressed by the zero value.

The results of length of char showed that P30HP, P60HP, and P120HP were under the second grade of CNS $7614(<10 \mathrm{~cm})$, but over that for HP and the control. It was 
also confirmed by the Duncan's multiple range tests (5\%), expressed by different alphabets. The results for the area of char indicated that the control panel and HP did not pass CNS $11668\left(<50 \mathrm{~cm}^{2}\right)$, but for three types of the panels, it was shown that the area of char was from 34.3 to $39.3 \mathrm{~cm}^{2}$, which was lower than $50 \mathrm{~cm}^{2}$ of CNS 11668 . From the above results, the panel in accordance with the study parameters, and the conditions of the pressure process for 30,60 , and $120 \mathrm{~min}$ with $4 \mathrm{MPa}$ at $120^{\circ} \mathrm{C}$ for $30 \mathrm{~min}$ of hot pressing, were able to qualify for CNS 11668 , and also reach the second grade of CNS 7614.

\section{ACKNOWLEDGEMENTS}

The authors are grateful to the Great \&Power Top Co. Ltd., Taiwan for providing the experimental materials, the fire retardant chemical, GP-202, Indoor type of High Efficiency Lumber Fireproof Lotion.

Contribution No. 374 of Taiwan Forestry Research Institute.

\section{REFERENCES}

Camino, G., L. Costa and M. P. Luda 1993 Mechanistic aspects of intumescent fire retardant system. Makromol. Chem., Macromol. Symp., 74: 71-83

Chen, T. Y., M. R. Hsu, H. C. Chen, C. H. Hsu 2000 Study on Densification of Wood Surface Layers. Forest Products Industries, 22(4): 1-12

China National Standard CNS 116681997 Flam-retardant plywood. China National Standard in Taiwan.

China National Standard CNS 76141994 Method of Test for Flammability of Thin Materials. China National Standard in Taiwan.

China National Standard CNS 8736 Method of Test for Flame-ability of Flame-Retardant Plywood. China National Standard in Taiwan.

Hsu, C. K., K. B. Cheng and J. S. Lee 2000 The applications of the thermal analysis techniques on polymer materials. J. Spinning and Weaving Engineering, Taiwan ROC, 18: 43-58

Hornsby, P. R. 1996 The Application of Hydrated Mineral Fillers As Fire Retardant and Somke Suppressing Additives Polymers. Macromol Symp, 108: 203-219

Hwang, G. S. 2003 Compression Set of China-fir Transversely Compressed Wood. Forest Products Industries, 22(2): 99-106

Kim, H. G., K. T. Kim 2000 Densification behavior of Tungsten-Fiber-Reinforced Copper Powder Compacts under Hot Isostatic Pressing. International J. of Mechanical Sciences, 42: 1339-1356

Kuwahara, M. 1996 Wood and Environment. Kaseisya (Japan), pp. 29-32

Lam, C. N. C., R Wu, L. D. Hair, A. W. Neumann 2002 Study on Advancing and Receding Contact Angles: Liquid Disporting as a Cause of Contact angle Hysteresis. Advances in Colloid and Interface Science 96: 169-191

Levan-Green, S. L., J. Livingston 2001 Exploring the Uses for Small-Diameter Trees. Forest Product J., 51(9): 10-21

Loidkis, S., D. Bakirtzis, A. P. Dimitrakopoulos 2003 Autoignition and Thermogravimetric Analysis of Forest Species Treated with Fire Retardant. Thermochimica Acta, 399: 31-42

Nakamura, K., M. MItta 1998 Fire Resistance Design of Wood Construction Building. Santyou (Japan), pp. 36-86

Okano, K., M. Suzuki, M. Haishi, K. Zonomoto, N. Zouta, T. Takahashi, H. Nitakai, I. Minadokuchi, T, Akiyama. 1995 Wooden Residence Environment - Handbook -. Asakusa Publication, Japan. pp. 114-122

Okuma, T. 1998 Wood-Based Resource Materials. Tokyo University Publication (Japan), pp. 17-20

Schaffer, E. 1977 State of structural timber fire endurance, Wood and Fiber, 19(2): 145-170 
Slifka, M. J. 1997 Fire Protection Design and Engineered Wood Products: A Guide for Specifier, Designers, and User. PFS Research Foundation, Madison. WI., pp. 173-191

Takeuchi, T. 2000 Porous Materials - Characterization, Production and Application. Fuji TecoSystem Publication. -. pp. 137-144

The Taiwan Forestry Bureau. 1995 The third survey of forest resources. Taiwan Forestry Bureau.

Tsai, W. C., S. Y. Wang, C. M. Tsai. 1995 Effect of Board Thickness, Fire-Retardant Retention and Degradation of Fire-Retardant Chemical on the Toxicity of Combustion Gas. Forest Products Industries, 20(2): 153-164

Yawa, M., S. Kawauthi, M. Iwamura 1997 Wood Science Series 12: Preservation and Durability. Kaseisy, pp.155-164

Zhu, S. and W. Shi 2001 Hyperbranched polyurethane acrylates containing phosphate as radiation curable flame-retardant coating material. Conference Proceedings, China, pp. 108-114 